\title{
WATERCRESS AND CHINESE CABBAGE IN A HYDROPONIC SYSTEM USING GROUNDWATER ${ }^{1}$
}

\author{
RAQUELE MENDES DE LIRA ${ }^{2 *}$, ENNIO FARIAS DE FRANÇA E SILVA ${ }^{3}$, ALEXSANDRO OLIVEIRA DA SILVA ${ }^{4}$, \\ PEDRO RÓBINSON FERNANDES DE MEDEIROS ${ }^{5}$, GERONNIMO FERREIRA DA SILVA ${ }^{3}$, HAMMADY RAMALHO \\ E SOARES $^{3}$
}

\begin{abstract}
Groundwater with high salt concentrations is common in the semiarid region of Brazil. It often makes them inappropriate to conventional agricultural production of vegetables. Therefore, the objective of this work was to evaluate watercress and Chinese cabbage crops under a nutrient film technique (NFT) hydroponic system using brackish groundwater. The experiment was carried out in the Poço do Boi region, in Ibimirim, Pernambuco, Brazil ( $8^{\circ} 32^{\prime} 15^{\prime \prime S}, 37^{\circ} 41^{\prime} 30^{\prime \prime} \mathrm{W}$, and altitude of $\left.431 \mathrm{~m}\right)$. The treatments used were: public water (T1), calcium sulfate water (T2), magnesium chloride water S1 (T3), calcium chloride water (T4), sodium chloride water (T5), and magnesium chloride water S2 (T6). A completely randomized experimental design was used, with six treatments and four replications, totaling 24 plots for each crop. The fresh and dry shoot weights and rates of relative and absolute growths were analyzed. The different waters used affected negatively the growth and yield of the watercress and Chinese cabbage plants. The calcium chloride water was the most suitable for the watercress production. However, none of the groundwaters used could be recommended for production of Chinese cabbage. The lowest growth rates $(5.88 \%$ to watercress and $0.75 \%$ to Chinese cabbage) of the fresh matter were found with the use of magnesium water.
\end{abstract}

Keywords: Nasturtium officinale R. Brassica pekinensis L. Water quality. Salinity. Nutrient film technique.

\section{CULTIVO DO AGRIÃO E DA COUVE CHINESA EM HIDROPONIA UTILIZANDO ÁGUAS SUBTERRÂNEAS}

\begin{abstract}
RESUMO - Em grande parte do semiárido é comum à presença de águas subterrâneas que apresentam concentrações de sais, tais que, muitas vezes, as tornam inapropriadas à produção agrícola de hortaliças de maneira convencional. Assim, objetivou-se com este trabalho avaliar o comportamento das culturas do agrião e da couve chinesa em hidroponia NFT (Nutrient Film Technique), submetidas à utilização de águas salobras subterrâneas. O experimento foi realizado no município Poço do Boi em Ibimirim-PE (8³2'15" de latitude Sul, 37²1'30" de longitude Oeste, e a uma altitude $431 \mathrm{~m}$. Os tratamentos foram designados como: T1 - água de abastecimento; T2 - água sulfatada cálcica; T3 - água cloretada magnesiana S1; T4 - água cloretada cálcica; T5 - água cloretada sódica e T6 - água cloretada magnesiana S2. O delineamento experimental foi inteiramente casualizados, com seis tratamentos e quatro repetições, totalizando 24 parcelas experimentais para cada cultura. Avaliou-se as produções de massa de matéria fresca e seca da parte aérea, taxas de crescimento relativo e absoluto. $\mathrm{O}$ uso das diferentes águas influenciou de maneira negativa no crescimento e rendimento da cultura do agrião e da couve chinesa, sendo a água cloretada cálcica a mais indicada para a produção do agrião. Já para a couve chinesa nenhuma das águas utilizadas é aconselhada para produção. As menores taxas de crescimento (5,88 \% para o agrião e $0,75 \%$ pra o couve) da massa de matéria fresca foram obtidas com o uso da água cloretada magnesiana $\mathrm{S} 2$.
\end{abstract}

Palavras-chave: Naturtium officinale R.. Brassica pekinensis L. Qualidade de água. Salinidade. Técnica do fluxo Laminar de Nutriente.

\footnotetext{
${ }^{*}$ Corresponding author

${ }^{1}$ Received for publication in $12 / 31 / 2018$; accepted in $07 / 08 / 2019$.

Paper extracted from the masters dissertation of the first author.

${ }^{2}$ Department of Agronomic, Universidade Federal Rural de Pernambuco, Serra Talhada, PE, Brazil; raquelelira@gmail.com - ORCID 0000-0002-9035-7788.

${ }^{3}$ Agricultural Engineering Post graduation, Universidade Federal Rural de Pernambuco, Recife, PE, Brazil; effsilva@uol.com.br - ORCID: 0000-0002-8652-503X, agrogefe@yahoo.com.br - ORCID: 0000-0002-3348-7252, hresoares@hotmail.com - ORCID: 0000-0003-34753417.

${ }^{4}$ Department Agricultural Engineering, Universidade Federal do Ceará, Fortaleza, CE, Brazil; alexsandro@ufc.br - ORCID: 0000-00015528-9874.

${ }^{5}$ Department Agricultural Engineering, Universidade Federal do Vale do São Francisco, Juazeiro, BA, Brazil; prfmede@yahoo.com.br ORCID: 0000-0003-4025-9538.
} 


\section{INTRODUCTION}

Water is a limiting factor for plant development in regions with low annual rainfall depths and high evapotranspiration, such as the semiarid region of Brazil; water scarcity in this region hinders agricultural production, causing economic and social losses that compromise the subsistence of the population (COSME et al., 2011).

Groundwater is an alternative for water supply (LUNA et al., 2013; SILVA et al., 2014). According to Cavazzana et al. (2012), groundwater is less susceptible to anthropogenic pollutants and has better quality because it infiltrates into the soil until it reaches a porous or crack aquifer and becomes available for use. Groundwater stored in cracks in the crystalline basement and in alluvium may present high concentrations of salts in its chemical composition due to contact with the source material of the rocks (OLIVEIRA et al., 2013).

Waters with high salinity are unsuitable for human consumption and pose risks to the environment, causing soil salinization and, consequently, agricultural desertification (SANTOS et al., 2011).

Researches have evaluated the viability of using brackish water for crops in hydroponic systems (SOARES et al., 2007; SILVA, 2012; JESUS et al., 2015), since crops present higher salt tolerance when grown is this system than in conventional cultivation system. This is due to the greater and constant water availability in this system and to the little or no contribution of the matric potential to the total water potential, resulting in a greater absorption of water and nutrients by plants for the same amount of salts.

One of the techniques of application of nutrient solution used in the hydroponic systems is the nutrient film technique (NFT), which consists of an intermittent passage of nutrient solution through a bed containing plants (MARTINEZ, 2017; FURLANI, 1998). According to Soares et al. (2007), these systems allow a sustainable use of brackish water from wells, mainly when using short-cycle crops that will be exposed to saline stress for a shorter time, thus, minimizing the damages caused by this stress.

Watercress is one of the main short-cycle vegetable crops produced in hydroponic systems in Brazil (OSHE et al., 2012). It is a leafy vegetable and a high-quality food that has good acceptance by consumers (HIRATA; HIRATA, 2015). Chinese cabbage is also a potential crop for hydroponics (SEABRA JÚNIOR; PEREIRA; ARAUJO 2014); this plant has leaves with a pronounced white mid rib, forming a globular-elongated compact head.

However, despite the economical relevance of these two vegetables, little information is found about their growth under hydroponic systems and the effects of using brackish groundwater for their production. Therefore, the objective of this study was to evaluate the growth of watercress and Chinese cabbage in NFT hydroponics using brackish groundwater.

\section{MATERIAL AND METHODS}

The research was conducted from January to March 2012 under a protected environment, at the Department of Agricultural Engineering of the Federal Rural University of Pernambuco, Recife, Pernambuco, Brazil $\left(8^{\circ} 01^{\prime} 05^{\prime \prime S}\right.$, 34 $4^{\circ} 56^{\prime} 48^{\prime \prime} \mathrm{W}$, and altitude of $6.5 \mathrm{~m}$ ). The average temperature during the experiments was $28{ }^{\circ} \mathrm{C}$. The protected environment had the following dimensions: $7.0 \mathrm{~m}$ wide, $24.0 \mathrm{~m}$ long, and $3.0 \mathrm{~m}$ to $4.5 \mathrm{~m}$ high.

The experiment was arranged in an NFT hydroponic system, with 48 plots - 24 in small hydroponic growth trays $(75 \mathrm{~mm})$, and 24 in large hydroponic growth trays $(150 \mathrm{~mm})$.

Each plot represented an independent NFT system consisting of a $3 \mathrm{~m}$ long growth tray, using a $220 \mathrm{~V}, 32 \mathrm{~W}$ circulating pump, a nutrient solution container $(60 \mathrm{~L}$ for the small growth tray plots, and $45 \mathrm{~L}$ for the large growth tray plots), and an automatic supply container $(15 \mathrm{~L})$ to replenish the water lost by evapotranspiration (SILVA et al., 2012).

The spacing between plants was $0.25 \mathrm{~m}$ and between growth trays was $0.30 \mathrm{~m}$ for the small growth trays; and $0.50 \mathrm{~m}$ between plants and $0.80 \mathrm{~m}$ between growth trays for the large growth trays. The average height of the growth trays was $0.85 \mathrm{~m}$ from the ground for the small growth trays, and $0.50 \mathrm{~m}$ for the large growth trays; both had four support points and $5.0 \%$ slope.

Each plot had a PVC tube conducting a nutrient solution pumped from the container to the top of the bench where the solution was injected into the hydroponic growth trays through a $4 \mathrm{~mm}$ diameter flexible microtube connected to the tube. The solution ran through the slope of the growth trays with at an average flow rate of $1.5 \mathrm{~L}$ (small growth trays) and $2.0 \mathrm{~L}$ (large growth trays) per minute; this flow was controlled by a flow valve. The excess solution that was not injected into the growth trays returned to the container through a return piping, helping the solution oxygenate.

Automatic supply systems in each plot replenished the water lost by evapotranspiration, which consisted of a $150 \mathrm{~mm}$ diameter PVC tube, which automatically flowed the water into the nutrient solution container, which had a float-tap.

A timer in the hydroponic system provided a regular interval of nutrient solution flows, which were scheduled to trigger every 15 minutes from 7:00 a.m. to 6:00 p.m. (MARTINEZ, 2017); from 6:00 p.m. to 07:00 a.m., irrigation was performed for 15 minutes every two hours. 
The experiments were conducted using local public water, which presented electrical conductivity (EC) of $0.3 \mathrm{dS} \mathrm{m}^{-1}$ and $\mathrm{pH}$ of 5.56. This water was used to prepare the standard nutrient solution of the control treatment and to simulate the waters of five different wells from different locations in Ibimirim, semiarid region of the state of Pernambuco, Brazil. The chemical composition of the waters is described in Table 1. These waters were used to prepare the nutrient solution and replenish the water lost by evapotranspiration.

Table 1. Chemical composition of waters from five different wells located in Ibimirim, semiarid region of the state of Pernambuco, Brazil.

\begin{tabular}{|c|c|c|c|c|c|c|c|c|c|c|}
\hline \multirow[b]{2}{*}{ Well } & \multirow{2}{*}{$\begin{array}{c}\begin{array}{c}\text { Electrical } \\
\text { conductivity }\end{array} \\
\left(\mathrm{dS} \mathrm{m}^{-1}\right)\end{array}$} & \multirow[b]{2}{*}{$\mathrm{pH}$} & \multicolumn{4}{|c|}{ Cations } & \multicolumn{4}{|c|}{ Anions } \\
\hline & & & $\mathrm{Ca}^{++}$ & $\mathrm{Mg}^{++}$ & $\mathrm{K}^{+}$ & $\mathrm{Na}_{(\mathrm{m}}^{+}$ & ${ }_{-1} \mathrm{Cl}^{-}$ & $\mathrm{CO}_{3}{ }^{2-}$ & $\mathrm{HCO}_{3}{ }^{-}$ & $\mathrm{SO}_{4}{ }^{2-}$ \\
\hline CS & 1.67 & 7.23 & 90.09 & 71.66 & 2.73 & 176.86 & 349.70 & 52.85 & 361.24 & 133.40 \\
\hline $\mathrm{MC} 1$ & 3.30 & 6.72 & 207.48 & 147.89 & 37.07 & 295.27 & 1105.55 & 36.79 & 500.94 & 65.00 \\
\hline $\mathrm{CC}$ & 4.71 & 7.08 & 436.80 & 185.86 & 18.00 & 476.24 & 1927.20 & 118.86 & 689.70 & 47.40 \\
\hline $\mathrm{SC}$ & 5.88 & 7.39 & 300.30 & 202.95 & 10.54 & 665.44 & 2230.53 & 0.00 & 419.82 & 0.00 \\
\hline MC2 & 13.84 & 7.67 & 60.06 & 1146.69 & 18.00 & 1283.89 & 4893.56 & 82.07 & 755.04 & 137.69 \\
\hline
\end{tabular}

$\mathrm{CS}=$ calcium sulfate water; $\mathrm{MC} 1=$ magnesium chloride water $\mathrm{S} 1 ; \mathrm{CC}=$ calcium chloride water; $\mathrm{SC}=$ sodium chloride water; and $\mathrm{MC} 2$ = magnesium chloride water $\mathrm{S} 2$.

The waters used in the treatments and location of their corresponding wells were, respectively: public water (PW), 8032'15"S, 37 41'30"W (T1); calcium sulfate water (CS), $8^{\circ} 25^{\prime} 25.7^{\prime \prime S} \quad 37^{\circ}$ 36'23.6"W (T2); magnesium chloride water S1 (MC1), 8032'11.5"S, 37041'28.5"W (T3); calcium chloride water (CC), $8^{\circ} 40^{\prime} 35.3^{\prime \prime S}, 37^{\circ} 40^{\prime} 43,4^{\prime \prime} \mathrm{W}$ (T4); sodium chloride water (SC), $8^{\circ} 27^{\prime} 10.2^{\prime \prime S}$, $37^{\circ} 41^{\prime} 16.2^{\prime \prime} \mathrm{W}$ (T5); and magnesium chloride water $\mathrm{S} 2$ (MC2), 842'39.9"S, $37^{\circ} 38^{\prime}$ '05.7"W (T6).

The groundwaters were classified by the Piper's diagram, according to the dominant ionic content resulting from the water-rock interaction. A completely randomized experimental design was used, with six treatments and four replications, totaling 24 experimental plots for each crop species.

Seeds of broadleaf watercress (Nasturtium officinale) and Chinese cabbage (Brassica pekinensis) were sowed on phenolic foam trays $(2 \times 2 \times 2 \mathrm{~cm})$.

Watercress seeds were sowed in longitudinal groves made on the phenolic foam trays, placing about 12 seeds of per cell. Chinese cabbage seeds were sowed in circular holes, placing three seeds per cell. Before sowing, the phenolic foam trays were washed under running water and treated with $0.01 \mathrm{~N}$ potassium hydroxide $(\mathrm{KOH})$ to eliminate the characteristic foam acidity and possible contaminants.

After sowing, the trays were kept in the dark until germination approximately 96 hours for the watercress, and 30 hours for the Chinese cabbage. Subsequently, the seedlings were transferred to a nursery and irrigated with $50 \%$ diluted nutrient solution (FURLANI, 1998) for 15 minutes with 15minute intervals, using a programmed timer.

The seedlings were thinned at 10 days after sowing (DAS) leaving five seedlings (watercress) and one seedling (Chinese cabbage) per cell. The plants were maintained in the nursery for 15 days and, then, transplanted to the growth trays (experimental plots) and subjected to the treatments (waters) with the nutrient solution proposed by Furlani, (1998) for leafy vegetables.

The $\mathrm{pH}$ and electrical conductivity (EC) of the solution were measured every two days using a $\mathrm{pH}$ meter and a digital conductivity meter, but the $\mathrm{pH}$ was not corrected to the ideal range (5.5 to 6.5 ), simulating field conditions, assuming the local farmer does not make $\mathrm{pH}$ correction. The nutrient solution was not replenished (nutrient solution exchange) during the experiments.

Both crops were periodically harvested every five days for the watercress, and one harvest every 15 days for the Chinese cabbage to analyze the absolute growth rate (AGR) and relative growth rate (RGR) as a function of water salinity.

The aerial part of each plant was weighed on a precision scale $(0.001 \mathrm{~g})$ to obtain the shoot fresh weight (SFW); then this sample was dried in a forced air-circulation oven at $65^{\circ} \mathrm{C}$ until constant weight to obtain the shoot dry weight (SDW).

The leaf area (LA) of the Chinese cabbage was determined by the ratio between the fresh weight of 5 leaf discs and the total fresh leaf weight. The leaf discs were obtained with a perforator of known area, avoiding the mid rib, as described by Benincasa (2003). The number of leaves (NL) in the Chinese cabbage was counted. The SFW and SDW were determined at the final harvest of the watercress (43 DAS) and Chinese cabbage (52 DAS) plants.

The data (SFW, SDW, NL, and LA) were subjected to analysis of variance, and the means of variables with significant effect were compared by the Tukey's test at 5\% probability. The calculated data of growth rates do not meet the basic assumptions for variance analysis; thus, these rates were presented as graphs, evaluating the curves drawn by the means of each data collection and regression analysis. 


\section{RESULTS AND DISCUSSION}

The electrical conductivity (EC) of the solution showed the salinization of the nutrient solution throughout the cycle of both crops, except in the control treatment (T1) (Figures 1A and 2A). This can be attributed to the use of brackish water for the replenishing of the water lost by evapotranspiration and for preparation of the nutrient solution of each treatment, which caused an accumulation of salts in the solution as a function of the plant water consumption. The replenishing of the water lost by evapotranspiration was performed with public water in the control treatment (T1), and did not caused salinization of the solution. The magnitude of the salinization was more significant for the Chinese cabbage, possibly due to the longer cycle and lower salt intake of this crop. Similar result was found by Lira et al. (2015) who subjected Chinese cabbage to different salinity $(\mathrm{NaCl})$ levels in the preparation and replenishing of the nutrient solution. Santos et al. (2011) and Soares et al. (2015) also found reductions in $\mathrm{EC}$ of the solution, however, only in the periods of high nutrient demand by the plants.

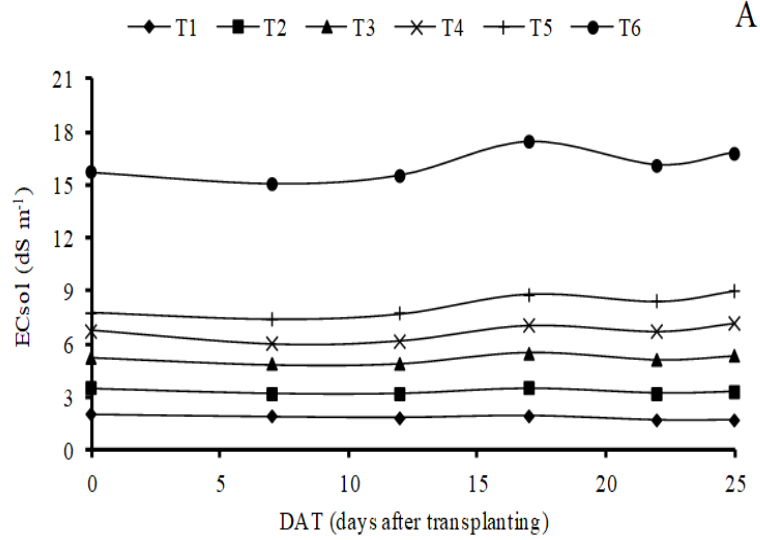

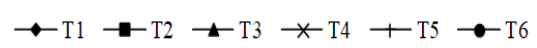
B

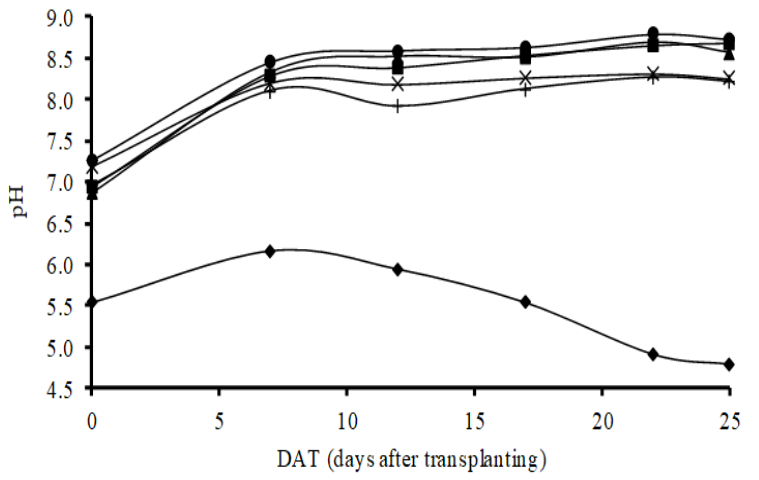

Figure 1. Electrical conductivity (EC) (A) and $\mathrm{pH}(\mathrm{B})$ of the nutrient solution during the experiment with watercress plants.

$\multimap \mathrm{T} 1 \rightarrow-\mathrm{T} 2 \rightarrow \mathrm{T} 3 \rightarrow \mathrm{T} 4 \rightarrow \mathrm{T} 5 \rightarrow \mathrm{T} 6$

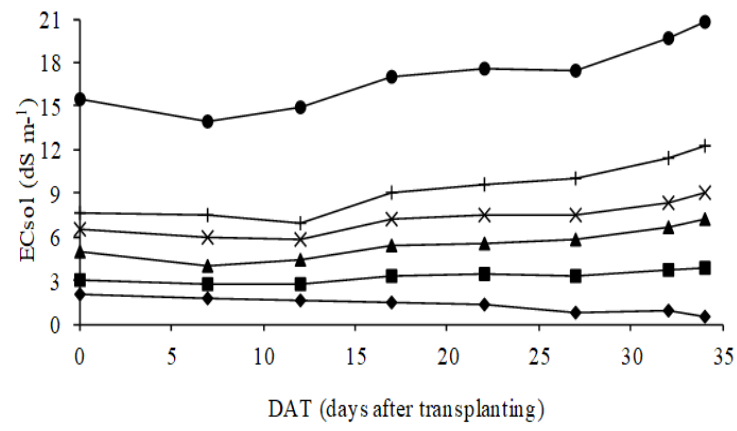

A
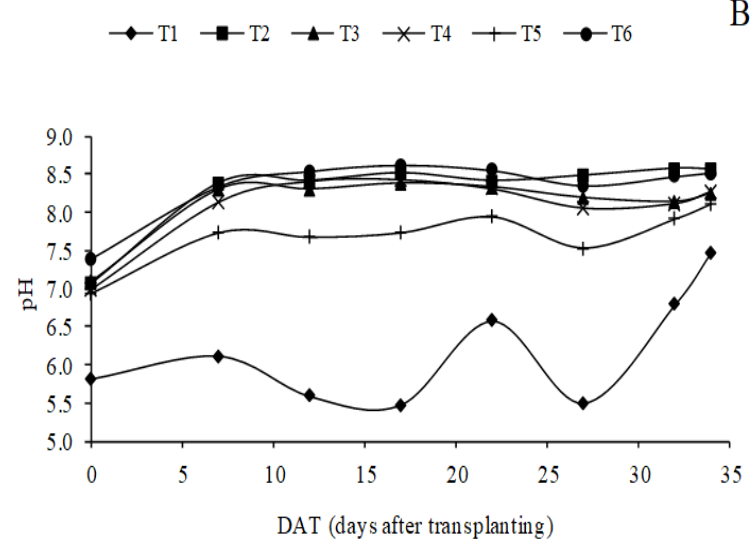

Figure 2. Electrical conductivity (A) and $\mathrm{pH}(\mathrm{B})$ of the nutrient solution during the experiment with Chinese cabbage plants.

The $\mathrm{pH}$ of the solution was higher than the proper range (5.5 to 6.5 ) since the beginning of the crop cycle, regardless of the water used, except for $\mathrm{T} 1$, which was within the proper range at the beginning and become acid over the watercress cycle and alkaline over the Chinese cabbage cycle (Figures $1 \mathrm{~B}$ and 2B). According to Cometti et al. (2008), plants may withstand $\mathrm{pH}$ between 4.5 and 7.5 without significant physiological effects. However, indirect effects, such as reduction in nutrient availability, can seriously compromise plant growth; $\mathrm{pH}$ changes may favor the formation of ionic species that are not readily available to plants, compromising nutrient absorption.

$\mathrm{PH}$ fluctuations during the crop cycle occur due to the absorption of cations and anions by plants. For example, when nitrogen is supplied in its nitric form, the absorption of anions is higher than that of cations and the $\mathrm{pH}$ increases. This may have occurred in the present experiment, although calcium nitrate and monoammonium phosphate were used as source of nitrogen, calcium, and phosphorus. According to Cometti et al. (2008), the absorption of 1 mole of $\mathrm{NO}_{3}{ }^{-}$is made by co-transporting of two 
moles of $\mathrm{H}^{+}$, whereas the absorption of 1 mole of $\mathrm{NH}_{4}^{+}$can pump one mole of $\mathrm{H}^{+}$to the outside of the cell. Thus, while $\mathrm{NO}_{3}{ }^{-}$absorption increases $\mathrm{pH}$, $\mathrm{NH}_{4}^{+}$absorption reduces it. Cometti et al. (2008) also state that in plants supplied with $\mathrm{NH}_{4}{ }^{+}$and $\mathrm{NO}_{3}{ }^{-}$, the $\mathrm{pH}$ of the solution may rise again when $\mathrm{NH}_{4}{ }^{+}$is absorbed and $\mathrm{NO}_{3}{ }^{-}$absorption becomes greater than that of $\mathrm{NH}_{4}^{+}$.

Regarding the production variables, the SFW and SDW of the watercress, and the SFW, SDW, LA, and NL of the Chinese cabbage plants were significantly affected using brackish waters. This denotes the sensitivity of leafy vegetables to brackish water from wells, as shown by Bione et al. (2014) and Soares et al. (2016).

The means of SFW (Figure 3A) and SDW (Figure 3B) of the watercress were 0.40 to $12.58 \mathrm{~g}$ per plant and 0.06 to $1.36 \mathrm{~g}$ per plant, respectively, depending on the water used. The control (T1) presented a higher SFW, differing from the other treatments, except T4, which presented no statistical difference from T1 (Figure 3A). The calcium chloride water (T4) had an EC of $4.71 \mathrm{dS} \mathrm{m}^{-1}$ (Table 1), but a higher amount of calcium than the other waters used. This nutrient is essential for plant development (RIBEIRO; SIMEÃO; SANTOS, 2015) and, at high concentrations, can minimize deleterious effects of sodium under salt stress. LaHaye and Epstein (1969) found that the addition of $\mathrm{Ca}^{2+}$ to the root environment attenuates the effects of $\mathrm{Na}^{+}$in some plant species because sodium destabilizes cell membranes, which are stabilized by calcium. This may have occurred in the present experiment, causing a greater development of plants subjected to the T4 treatment, resulting in higher SFW.

The SDW of plants treated with magnesium chloride S1 (T3), calcium chloride (T4), and sodium chloride (T5) waters were similar to that of the control (T1), whereas those treated with magnesium chloride water S2 (T6) differed from the other treatments (Figure 3B). Silva (2012) evaluated broadleaf watercress under six different brackish waters (2.09 to $11.80 \mathrm{dS} \mathrm{m}^{-1}$ ) and a control and found SFW of 18 to $61 \mathrm{~g}$ per plant, and SDW of 1.7 to $5.1 \mathrm{~g}$ per plant.

The lowest SFW and SDW found in the present study are due to the higher concentration of ions, especially $\mathrm{Cl}^{-}$, since the excess of this ion damages leaf tissues, inhibiting plant development (SANTOS et al., 2011; SOARES et al., 2007)
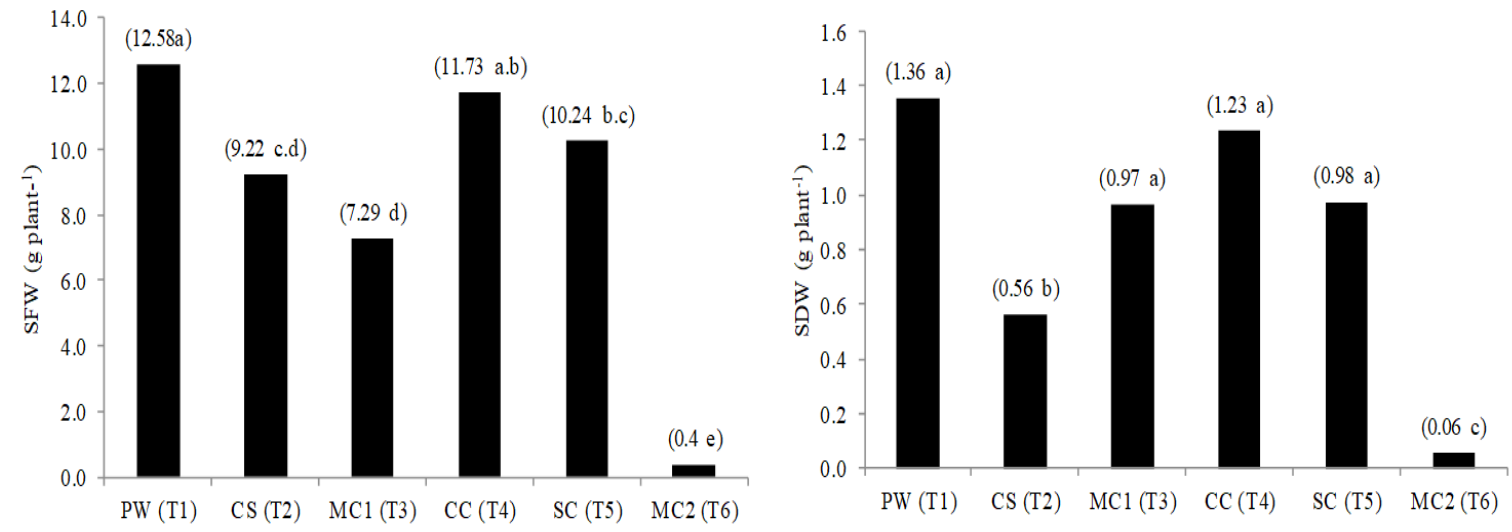

Figure 3. Shoot fresh weight (SFW) (A) and shoot dry weight (SDW) (B) of watercress plants as a function of use of different brackish waters - PW $(\mathrm{T} 1)=$ public water $($ control); CS $(\mathrm{T} 2)=$ calcium sulfate water; $\mathrm{MC} 1(\mathrm{~T} 3)$ = magnesium chloride water S1; CC (T4) = calcium chloride water; SC (T5) = sodium chloride water; and MC2 (T6) = magnesium chloride water S2.

The SFW means found for the Chinese cabbage were 3.25 to $986.96 \mathrm{~g}$ per plant; the control treatment presented the highest mean, differing statistically from the other treatments (Figure 4A). The SDW means found this crop were between 0.55 and $44.51 \mathrm{~g}$ per plant. T3 (magnesium chloride water $\mathrm{S} 1$ ) and T5 (sodium chloride water) presented no statistic difference in SDW. The control (T1) differed from the other treatments; T6 also differed from the other treatments, presenting the lowest SFW and SDW (Figure 4B). These results were due to the different salt concentrations in the waters used (Table 1), showing that the evaluated crops present different responses to the same salt concentration.
The watercress presented at least one (T4) similar result to the control, whereas the Chinese cabbage was more sensitive to the different waters and salinities, since the waters used also had increasing salt levels in the total concentration (EC of the water).

Silva et al. (2016) evaluated coriander crop in hydroponics and found reductions in fresh and dry weights of plants as the salt concentration were increased. Reductions in SFW and SDW of leafy vegetables were also found by Lira et al. (2015) with Chinese cabbage and by Soares et al. (2015) with hydroponic lettuce crop, despite their different brackish water managements. 

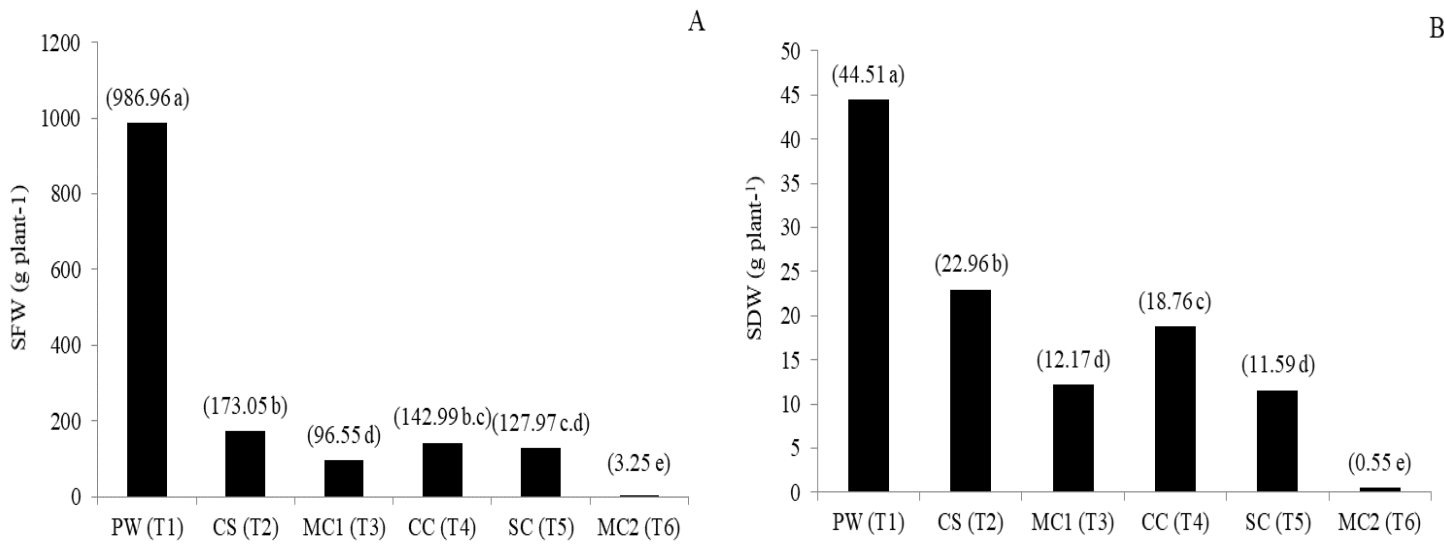

Figure 4. Shoot fresh weight (SFW) (A) and shoot dry weight (SDW) (B) of Chinese cabbage plants as a function of different brackish waters - PW $(\mathrm{T} 1)$ = public water (control); CS (T2) = calcium sulfate water; MC1 $(\mathrm{T} 3)=$ magnesium chloride water S1; CC (T4) = calcium chloride water; SC (T5) = sodium chloride water; and MC2 (T6) = magnesium chloride water S2.

The number of leaves (NL) of the Chinese cabbage was 7.50 to 30.25 , with no statistical difference between T1 (public water; control) and T2 (calcium sulfate water). T6 (magnesium chloride water S2) differed from the other treatments and had the lowest NL (7.50) (Figure 5A). Studies have found negative effects of brackish waters on number of leaves in coriander (REBOUÇAS et al., 2013), hydroponic rocket (SILVA et al., 2012), and sunflower (SANTOS JÚNIOR et al., 2015), due to the salinity of the nutrient solution, denoting that, despite the hydroponic system facilitates water absorption by plants, the development of some species under high salt water concentrations may be compromised.

The leaf area (LA) of the plants were between
22700.02 and $2069.52 \mathrm{~cm}^{2}$ per plant, with no statistical difference as a function of the different waters used, except for the control (T1), which differed from the other treatments, presenting the highest LA (Figure 5B).

A progressive decrease in LA as a function of water salinity was shown by Soares et al. (2015); however, the Chinese cabbage showed a high sensitivity to the waters used in the present study, regardless of the water EC. Some element in the water chemical composition $(\mathrm{Mg}, \mathrm{Na}, \mathrm{Cl})$ probably affected negatively the LA, regardless of the EC of the water (1.67 to $13.84 \mathrm{dS} \mathrm{m}-1)$. Therefore, the water chemical composition may be more damaging to this crop than its EC
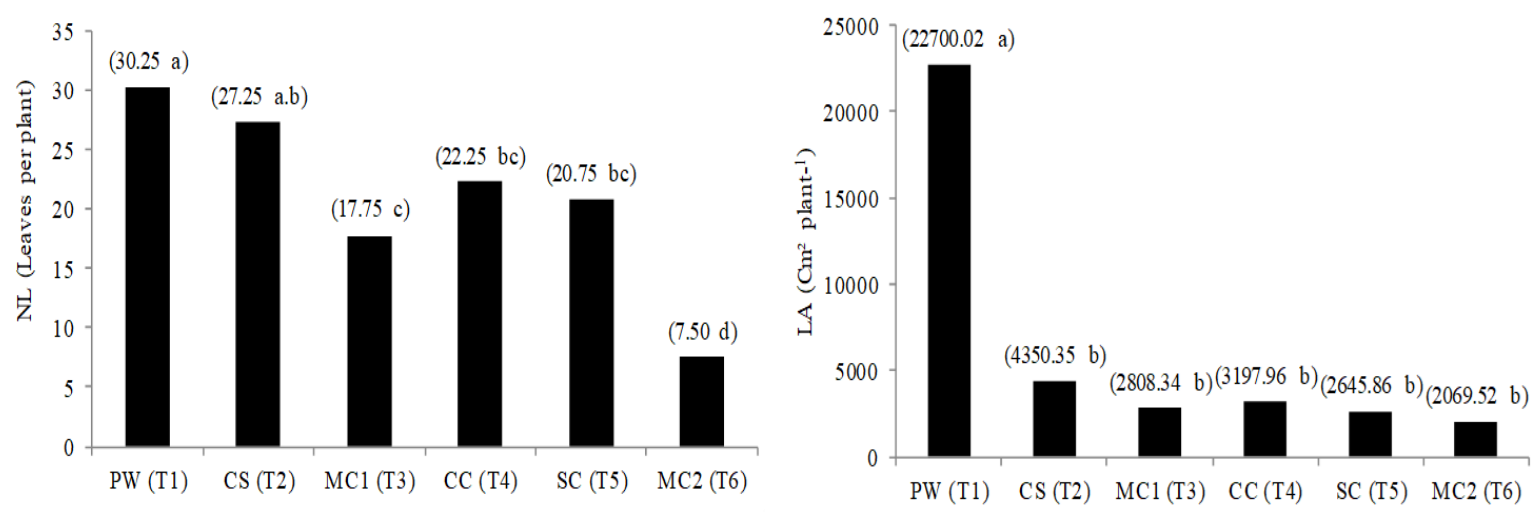

Figure 5. Number of leaves (NL) (A) and leaf area (LA) (B) of Chinese cabbage as a function of different brackish waters - PW $(\mathrm{T} 1)$ = public water $($ control); $\mathrm{CS}(\mathrm{T} 2)=$ calcium sulfate water; $\mathrm{MC1}(\mathrm{T} 3)$ = magnesium chloride water S1; $\mathrm{CC}(\mathrm{T} 4)$ = calcium chloride water; SC (T5) = sodium chloride water; and MC2 (T6) = magnesium chloride water S2.

Regarding the crop growth rates, the highest absolute growth rate (AGR) and relative growth rate ( (RGR) in shoot fresh and dry matters of the watercress plants were found with the use of public water (T1) (Figure 6). The fresh and dry AGR of plants in $\mathrm{T} 4$ were the most similar to that of the control, i.e., presenting higher plant growth rate than those of plants in the other treatments, reaching 1.33 (fresh AGR) and 0.12 (dry AGR) g day ${ }^{-1}$ at 26 days after transplanting (DAT); while the control presented 1.46 (fresh AGR) and 0.15 (dry AGR) g day $^{-1}$ (Figures 6A and 6C). The high $\mathrm{Ca}$ 
concentration in these waters probably contributed to mitigate the effects of salinity. According to Martinez (2017), a constant supply of $\mathrm{Ca}$ is necessary to meet the continuous growth of plants due to the Ca immobility.

The largest difference in growth rate between the watercress plants at 7 DAT was found between plants of the control (T1) and T6 (with the highest salinity), reaching $5.88 \%$ (fresh AGR) and $11.11 \%$ (dry AGR) (Figures 6A and 6C). These variations tend to increase as the plant grows, with the control reaching a 60.7-fold higher fresh AGR when compared to T6, which present a fresh AGR of 0.024 $\mathrm{g} \mathrm{day}^{-1}$ at the end of the cycle (Figure 6A). The fresh AGR in T4 was 1.12-fold lower than that of the control at the end of the cycle. The other treatments had similar fresh and dry AGR, but different from the control (Figure 6).

The relative growth rate (RGR) is based on the plant weight as a function of initial weight (BENINCASA, 2003). This is a more accurate measurement, as it considers the allocated matter over the existing matter proportionally to its size. According to Cometti et al. (2008), AGR is an idea of the individual plant development over a period, and RGR is an instant view of a plant's production efficiency from a growth derivative over a period.

The fresh and dry RGR of the watercress plants were higher in the first evaluation, decreasing in the following evaluations (Figures 6B and 6D) in all treatments. Therefore, a rapid matter accumulation occurs at the beginning of plant development, followed by a decrease. This can be explained by the plants' high respiratory activity at the beginning of the cycle and by increasing of selfshading (HIRATA; HIRATA, 2015) over time.

In general, the highest fresh and dry RGR were found in plants in the control (T1), followed by that of plants in T4 (calcium chloride water), which reached a fresh RGR of 1.36-fold higher than that in the control at the end of the cycle (Figure 6B). The high availability of $\mathrm{Ca}$ in $\mathrm{T} 4$ may have contributed to plant growth and mitigated the effects of salinity (MARTINEZ, 2017).
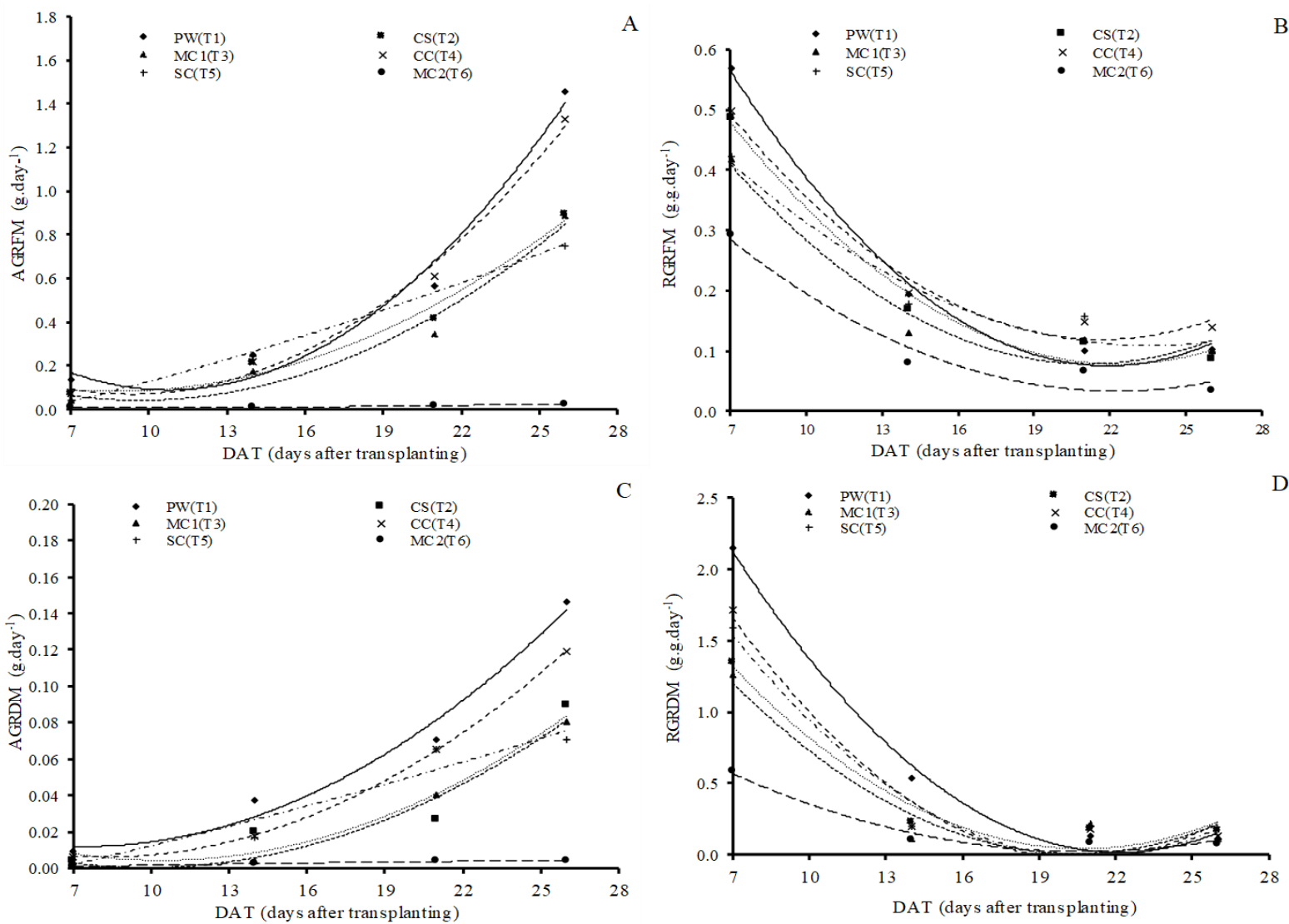

Figure 6. Absolute growth rate of fresh matter (AGRFM) (A); Relative growth rate of fresh matter (RGRFM) (B); Absolute growth rate of dry matter (AGRDM) (C); Relative growth rate of dry matter (RGRDM) (D) of watercress plants treated with different brackish waters - PW (T1) = public water (control); CS (T2) = calcium sulfate water; MC1 (T3) = magnesium chloride water $\mathrm{S} 1 ; \mathrm{CC}(\mathrm{T} 4)=$ calcium chloride water; $\mathrm{SC}(\mathrm{T} 5)=$ sodium chloride water; and $\mathrm{MC} 2(\mathrm{~T} 6)=$ magnesium chloride water $\mathrm{S} 2$. 
The growth rates of the Chinese cabbage plants were evaluated through growth curves. In general, the control (T1) presented higher fresh and dry AGR and RGR than the other treatments (Figure 7). The fresh AGR and dry AGR of the Chinese cabbage plants in the first evaluation (14 DAT) did not present great variations, as the watercress plants; the highest difference was found between the control (T1) and T6, reaching $0.75 \%$ (fresh AGR) and $3.70 \%$ (dry AGR) (Figures 7A and 7C). This variation increased over the crop cycle; the fresh and dry AGR values found in plants in $\mathrm{T} 4$ were the most similar to the control; T4 presented fresh AGR of 10.78 and dry AGR of $0.78 \mathrm{~g} \mathrm{day}^{-1}$, while the control presented fresh AGR of 42.24 and dry AGR of $1.321 \mathrm{~g} \mathrm{day}^{-1}$. The treatment with the highest salt concentration (T6) showed plants with the lowest growth rates, reaching a fresh AGR of 301.7-fold lower than that in plants of the control (T1) at the end of the cycle (Figure 7A). The fresh RGR and dry RGR of the Chinese cabbage were high at 14 DAT in all treatments; the control (T1) had the highest rates in this period (0.29 and $0.26 \mathrm{~g} \mathrm{day}^{-1}$, respectively) (Figures 7B and 7D).
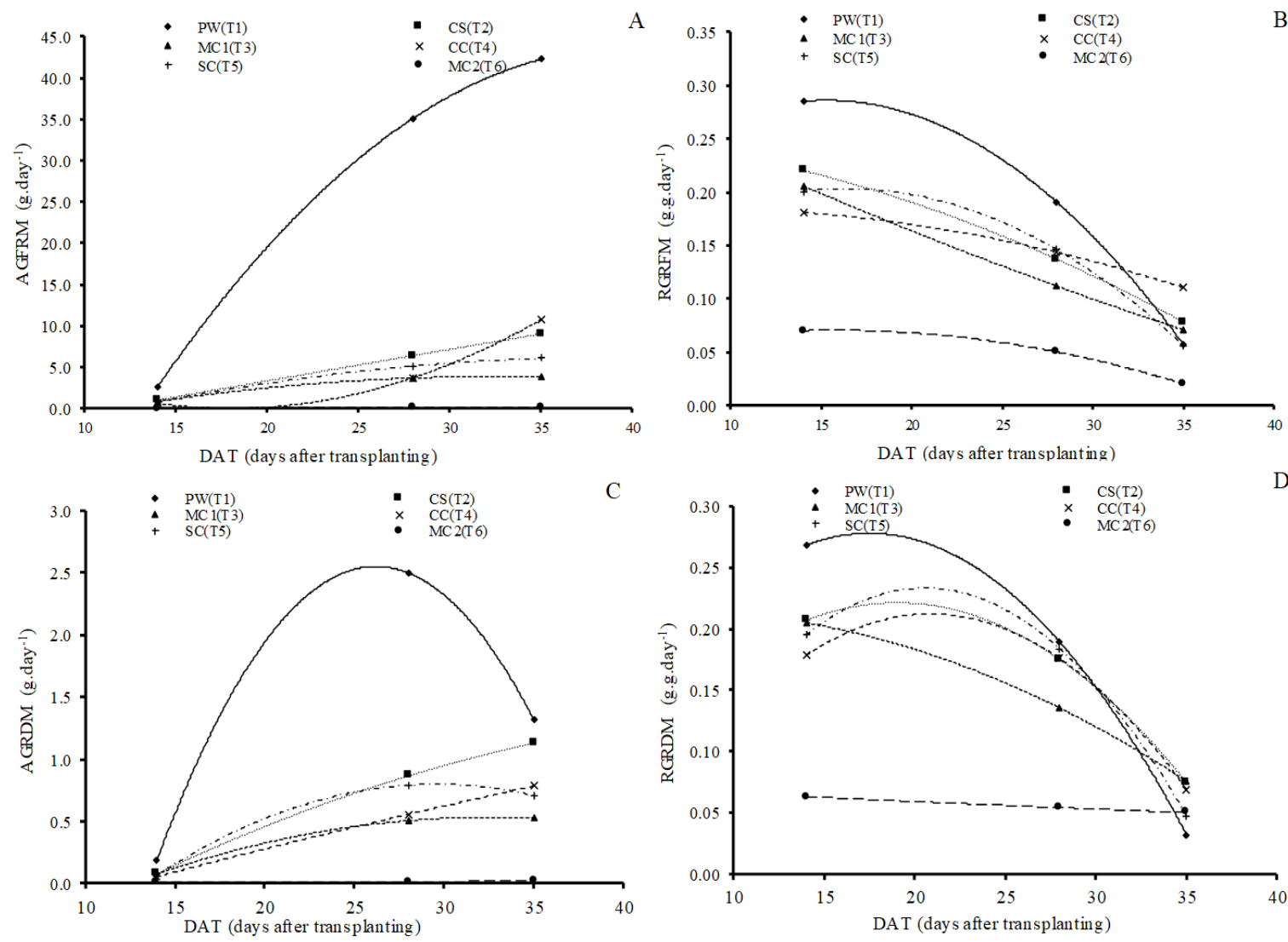

Figure 7. Absolute growth rate of fresh matter (AGRFM) (A); Relative growth rate of fresh matter (RGRFM) (B); Absolute growth rate of dry matter (AGRDM) (C); Relative growth rate of dry matter (RGRDM) (D) of Chinese cabbage plants treated with different brackish waters-PW $(\mathrm{T} 1)=$ public water (control); CS $(\mathrm{T} 2)=$ calcium sulfate water; $\mathrm{MC} 1$ (T3) = magnesium chloride water S1; CC (T4) = calcium chloride water; SC (T5) = sodium chloride water; and MC2 (T6) = magnesium chloride water S2.

The growth curves of the other treatments followed the same trend, but with lower results than the control; the higher the salinity level, the lower was the RGR at the beginning of the cycle. The following evaluations showed a continuous decrease up to 35 DAT for all treatments. According to Lima, Peixoto and Ledo (2007), any weight increment over a given period is directly related to the size achieved in the previous period.

The fresh and dry RGR of the plants at 35 DAT decreased with similar values. According to Cometti et al. (2008), this indicates the beginning of senescence, when the net assimilation becomes negative. The control presented a lower dry RGR at the end of the cycle than the other treatments, including T6, indicating almost zero growth as a function of the accumulated matter (Figure 7D).

\section{CONCLUSION}

The different brackish groundwaters, simulated from wells in the semiarid region of Brazil, had negative effects on the growth and yield of watercress and Chinese cabbage plants, when used for the preparation of nutrient solution and 
replenishing of the water lost by evapotranspiration in an NFT hydroponic system. The treatment with calcium chloride water was the most suitable to produce watercress. The water from any of the analyzed wells are recommended to produce Chinese cabbage. The lowest growth rates of watercress and Chinese cabbage plants were found with the use of chloride magnesium water S2. The number of leaves and leaf area of Chinese cabbage plants were affected negatively using the evaluated waters.

\section{ACKNOWLEDGEMENTS}

The authors thank the Postgraduate Program in Agricultural Engineering of the Federal Rural University of Pernambuco (UFRPE) for providing the environment for the conduction of the experiment; the Brazilian Coordination for the Improvement of Higher Education Personnel (CAPES) and Brazilian National Council for Scientific and Technological Development (CNPq) for granting scholarships; and the National Institute of Science and Technology in Salinity (INCTSal) for financial support for the development of this work.

\section{REFERENCES}

BENINCASA, M. M. P. 2003. Análise de crescimento de plantas: noções básicas. 2. ed. Jaboticabal, SP: FUNEP, Brasil. 41 p.

BIONE, M. A. A. et al. Crescimento e produção de manjericão em sistema hidropônico NFT sob salinidade. Revista Brasileira de Engenharia Agrícola e Ambiental, v. 18, n. 12, p. 1228-1234, 2014.

CAVAZZANA, G. H. et al. Análise de agressividade e incrustação das águas subterrâneas na região urbana de Campo Grande - MS. Revista águas subterrâneas, v. 26, n. 1, p. 83-97, 2012.

COMETTI, N. N. et al. Efeito da concentração da solução nutritiva no crescimento da alface em Cultivo hidropônico-sistema NFT. Horticultura Brasileira, v. 26, n. 2, p. 252-257, 2008.

COSME, C. R. et al. Produção de tomate hidropônico utilizando rejeito da dessalinização na solução nutritiva aplicados em diferentes épocas. Revista Brasileira de Engenharia Agrícola a ambiental, v. 15, n. 5, p. 499-504, 2011.

FURLANI, P. R. Instruções para o cultivo de hortaliças de folhas pela técnica de hidroponia NFT. 1. ed. Campinas, SP: IAC, 1998. 30 p. (Boletim técnico, 168).
HIRATA, A. C.; HIRATA, E. K. Desempenho produtivo do agrião d'água cultivado em solo sob telas e sombreamento. Pesquisa Agropecuária Brasileira, v. 50, n. 10, p. 895-901, 2015.

JESUS, C. G. et al. Production of rocket under salt stress in hydroponic systems. Horticultura Brasileira, v. 33, n. 4, p. 493-497, 2015.

LAHAYE, P. A.; EPSTEIN, E. Salt toleration by plants: enhancement with calcium. Science, v. 166, n. 3905, p. 395-396, 1969.

LIMA, J. F.; PEIXOTO, C. P.; LEDO, C. A. S. Índices fisiológicos e crescimento inicial de mamoeiro (carica papaya L.) em casa de vegetação. Ciência e Agrotecnologia, v. 31, n. 5, p. 1358-1363, 2007.

LIRA, R. M. et al. Production water consumption and nutrient content of chinese cabbage grown hydroponically in brackish water. Revista Ciência Agronômica, v. 46, n. 3, p. 497-505, 2015.

LUNA, N. R. S. et al. Dinâmica do nitrato e cloreto no solo e a qualidade das águas subterrâneas do distrito de irrigação Baixo Acaraú, CE. Revista Agro@mbiente, v. 7, n. 1, p. 53-62, 2013.

MARTINEZ, H. E. P. Manual prático de hidroponia. 3. ed. Viçosa, MG: Aprenda fácil, 2017. $286 \mathrm{p}$.

OLIVEIRA, H. A. et al. Qualidade de águas de poços dos assentamentos da chapada do Apodi-RN para o uso na agricultura. Holos, v. 1, n. 29, p. 6472, 2013.

OSHE, S. et al. Produção e composição química de hortaliças folhosas em hidroponia. Bioscience Journal, v. 28, n. 2, p. 155-163, 2012.

REBOUÇAS, J. R. L. et al. Cultivo hidropônico de coentro com uso de rejeito salino. Irriga, v. 18, n. 4, p. 624-634, 2013.

RIBEIRO, A. A.; SIMEÃO, M.; SANTOS, D. P. Crescimento da alface cultivada em solução nutritiva com diferentes concentrações de cálcio. Revista Brasileira de Engenharia de Biossistemas, v. 9, n. 4, p. 298-303, 2015.

SANTOS, A. N. et al. Produção de alface em NFT e floating aproveitando água salobra e o rejeito da dessalinização. Revista Ciência Agronômica, v. 42, n. 2, p. 319-326, 2011.

SANTOS JÚNIOR, J. A. et al. Crescimento do girassol em sistema hidropônico sob estresse salino e densidade de plantio. Irriga, v. 20, n. 2, p. 233-247, 
2015.

SEABRA JÚNIOR, S.; PEREIRA, A. S.; ARAUJO, K. L. Desempenho de cultivares de couve-chinesa em Cáceres-MT. Horticultura Brasileira, v. 32, n. 4, p. 504-507, 2014.

SILVA, A. O. et al. Consumo hídrico da rúcula em cultivo hidropônico NFT utilizando rejeitos de dessalinizador em Ibimirim-PE. Irriga, v. 17, n. 1, p. 114-125, 2012.

SILVA, J. L. A. et al. Uso de águas salinas como alternativa na irrigação e produção de forragem no semiárido nordestino. Revista Brasileira de Engenharia Agrícola e Ambiental, v. 18, sup., p. 567-572, 2014.

SILVA, J. S. Produção de hortaliças folhosas com uso de águas salobras do Semiárido e do Recôncavo Baiano utilizando sistema hidropônico NFT. 2012. 78 f. Dissertação (Mestrado Ciências Agrárias: Área de concentração em Agricultura Irrigada e Sistemas Hidroagrícolas) - Universidade Federal do Recôncavo da Bahia, Cruz das Almas, Brasil, 2012.

SILVA, M. G. et al. Frequency of recirculation of nutrient solution in hydroponic cultivation of coriander with brackish water. Revista Brasileira de Engenharia Agrícola e Ambiental, v. 20, n. 5, p. 447-454, 2016.

SOARES, H. R. et al. Lettuce growth and water consumption in NFT hydroponic system using brackish water. Revista Brasileira de Engenharia Agrícola e Ambiental, v. 19, n. 7, p. 636-642, 2015.

SOARES, H. R. et al. Mineral nutrition of crisphead lettuce grown in a hydroponic system with brackish water. Revista Caatinga, v. 29, n. 3, p. 656-664, 2016.

SOARES, T. M. et al. Produção de alface utilizando águas salinas em sistema hidropônico. Irriga, v. 12, n. 2 , p. $235-248,2007$. 